\section{Monitoring adherence to antiretroviral treatment in Brazil: an urgent challenge}

\author{
Monitoramento da adesão ao tratamento \\ antirretroviral no Brasil: um urgente desafio
}

\author{
${ }^{1}$ Universidade Federal de São \\ João Del-Rei, Divinópolis, \\ Brasil. \\ 2 Faculdade de Ciências \\ Econômicas, Universidade \\ Federal de Minas Gerais, Belo \\ Horizonte, Brasil. \\ 3 Faculdade de Farmácia \\ Universidade Federal de \\ Minas Gerais, Belo Horizonte, \\ Brasil. \\ 4 Faculdade de Medicina \\ Universidade Federal de \\ Minas Gerais, Belo Horizonte, \\ Brasil. \\ Correspondence \\ G. M. Rocha \\ Universidade Federal de São \\ João Del-Rei. \\ Av. Sebastião Gonçalves Coelho \\ 400, Divinópolis, $M G$ \\ 35501-296, Brasil. \\ gusrocha.mg@gmail.com
}

\section{Abstract}

The aim of this study was to describe the effect of non-adherence on the main laboratory outcomes, TCD4+ lymphocyte count and viral load, routinely used to monitor patients initiating treatment according to three different approaches to measure adherence to antiretroviral therapy. Among 288 participants, 22.9\%, 31.9\% and 74.3\% were considered non-adherent, according to medical charts, self-report and pharmacy records, respectively. Depending on the adherence measures used, the average gain in TCD4+ lymphocyte count ranged from 142.4 to 195.4 cells/ mm3 among adherent patients, and from 58.5 to 99.8 lymphocytes TCD4+/mm3 among those nonadherent. The average reduction on viral load ranged from 4.25 to 4.62 log copies/mL among the adherent patients, and from 1.99 to $4.07 \mathrm{log}$ among those non-adherent. Monitoring antiretroviral adherence should be considered a priority in these public AIDS referral centers in order to identify patients at high risk of developing virologic failure. Early interventions are necessary in order to maintain the initial therapeutic regimens for longer periods.

Anti-Retroviral Agents; Acquired Immunodeficiency Syndrome; Viral Load; CD4 Lymphocyte Count; Medication Adherence
Gustavo Machado Rocha ${ }^{1}$

Carla Jorge Machado 2

Francisco de Assis Acurcio 3

Mark Drew Crosland Guimarães 4

\section{Introduction}

The highly active antiretroviral therapy (HAART), introduced in 1996, had a great impact in the reduction of morbidity and mortality of individuals living with HIV/AIDS. In Brazil, the universal distribution of antiretroviral (ARV) medication by the Unified National Health System (SUS) was guaranteed by law sanctioned in the same year ${ }^{1}$. In this scenario, AIDS was no longer a disease with high letality rate, and it started being considered a potentially controllable chronic disease. Initial studies that evaluated the effect of antiretroviral therapy (ART) showed a reduction of about $70 \%$ in mortality and of $80 \%$ in the incidence of opportunistic infections 2. According to data provided by the Ministry of Health 3, there were 15,156 AIDS-related deaths in Brazil in 1995 and 11,060 in 2007, which represents a reduction of about $27 \%$ in the total number of deaths in the country. In recent years, with the great availability of therapeutic choice, including drugs that are newer, more powerful, safer and present more convenient dosage 4 , the possibility of reaching these benefits and improving the quality of life of these patients is even greater.

However, the success of ART depends on many factors such as issues related to the access to treatment and health services, viral characteristics and immunity response, besides behavioral 
factors related to an individual, especially adherence to the treatment. According to guidelines of the Ministry of Health 5, adherence must be understood as a complex, wide, comprehensive, dynamic, and multifactorial process, determined by factors related to the individual, the health team and the social network.

Based on this complexity, measuring adherence to antiretroviral medication is difficult to be precisely performed, with no gold standard defined for its ascertainment. There is great variability in the available adherence measurement with different implications for clinical and research practices. Among them we mention the self-report verified by structured interviews, pills count, medical and pharmacy records, electronic devices, monitoring of therapeutic serum level, pictorial methods (e.g. daily registries of medications, self-applicable interview 6,7) and, finally, combined methods are examples of adherence measurements used in several studies 8,9. All of these measurements present limitations and problems, either practical or methodological, which may overestimate or underestimate the adherence. This wide variability complicates the interpretation of results and their comparison. The measurement of adherence by self-report use is the most frequently used and it has the advantages of a more accessible costs, practicality and convenience of application, besides reasonable correlation with virologic outcomes. Conversely, there are disadvantages such as lack of standard questions, low sensitivity and a tendency to overestimate adherence 10 .

In order to obtain therapeutic success and reach undetectable plasma levels of HIV viral load, high levels of adherence, usually $95 \%$ or more, are necessary, as shown by several studies 11. In addition to providing lower viral replication, high adherence, also provides longer survival, lower incidence AIDS related diseases, fewer hospitalizations 12, better quality of life 13, reduction of HIV transmission, and reduced emergence of virus strains resistant to ARV 14 . However, the great variability in the definition of non-adherence used in the studies, both in the cutoff points (ranging from 80 to $100 \%$ of prescribed doses), as well as in the evaluated treatment period (from one day up to 12 months) complicates national or international comparisons. More recent studies tend to be more conservative with higher cutoff points and wider recall periods.

A complete adherence ART must be understood as the primary objective of health services caring for people living with HIV/AIDS. Despite this, Brazilian studies indicate average rates of non-adherence ranging between $5.7 \%$ and $67 \%$, with $43.2 \%$ of studies reporting values between $17.5 \%$ and $30 \% 8$, showing a critical situation for clinical monitoring of patients. In a more recent study, Wachholz \& Ferreira 15 evaluated children up to 12 years living in the city of Porto Alegre, Rio Grande do Sul State, and found a high rate of non-adherence (about 50\% of the participants). Another study 16, performed in the city of Tubarão, Santa Catarina State, found a non-adherence rate ranging from $19.5 \%$ to $52.5 \%$, depending on the definition of adherence and the analyzed period. However, in other multicenter studies recently performed in the Federal District 17 and in the state of Pernambuco 18, 23.3\% and $25.7 \%$ of the participants were, respectively considered non-adherent.

Thus, it is necessary to implement standardized procedures to monitor the adherence among service users in order to enable early detection of non-adherence and the implementation of appropriate intervention strategies, ideally before the emergence of viral resistance and the occurrence of complications related to AIDS. In addition to the individual benefits, these actions have the potential to reduce the costs with medications as simpler treatment regimens remain effective for extended time.

The main purpose of this study was to describe the effect of non-adherence on the main laboratory outcomes, i.e., increase in TCD4+ lymphocytes counts and reduction in the HIV viral load, according to three different methods of measuring adherence (self-report, registry of pharmacy dispensation and medical records) among patients starting antiretroviral treatment in two reference public health services in the city of Belo Horizonte, state of Minas Gerais.

\section{Methodology}

\section{Subjects and design}

This study is part of ATAR project 19, a prospective concurrent study whose main purpose was to evaluate adherence to antiretroviral treatment among individuals starting therapy. Methodological details have been previously published 20. The project was carried out in two HIV/ AIDS public referral services in the city of Belo Horizonte, Orestes Diniz Center for Training and Reference of Infectious and Parasite Diseases (CTR-DIP - Municipality of Belo Horizonte and Federal University of Minas Gerais - UFMG), and Eduardo de Menezes Hospital outpatient center (HEM - Hospital Foundation of Minas Gerais). After the first ARV prescription, naïve treated patients were monitored for a period of up to 12 
months to evaluate the occurrence of non-adherence to treatment.

The patients were recruited between May 2001 and May 2002 and monitored until May 2003. Inclusion criteria were patients confirmed with HIV infection and indication for antiretroviral therapy according to the Brazilian recommendations in the period 21, without history of previous ARV use, age 18 years old or over, and who agreed to participate and had their medication provided by one of the participant centers. For this analysis, pregnant women were excluded due to the specificity of their antiretroviral treatment whose early interruption may occur due to medical indication. The ATAR Project was approved by the Ethical Research Committee of both participant services and the UFMG - COEP (ETIC 106/99).

Semi-structured interviews were applied at the moment of the ARV dispensation (baseline interview), when social economic and demographic data were collected (e.g. age, skin color, marital status, education level), vulnerability characteristics to HIV/AIDS (e.g. use of drugs, sexual behavior), and variables indicator of health services utilization (e.g. date of antiHIV test, duration of medical follow-up, knowledge about HIV/AIDS). Subsequent interviews were performed in the first, fourth and seventh month after the beginning of treatment (followup interviews), with the collection of behavioral characteristics and information related to ART (e.g. occurrence of side effects and change of medication, difficulties and easiness related to treatment, adherence to the ARV regimens). The maximum period of follow-up was 12 months. Monthly ARV dispensations records were collected in the pharmacies of the participating centers after the follow-up period. Clinical and laboratory data were obtained from medical records (e.g. transmission category, duration of follow-up, hospitalizations and AIDS related conditions, results of TCD4 + lymphocytes counts and HIV viral load). All instruments used in data collection were previously tested in a pilot study.

Continuous variables obtained during the baseline interview, i.e. age, education level, income, time between HIV+ diagnosis and the first prescription of ARV, and time between the first medical visit and first prescription of ARV were categorized using the median value as cutoff point.

\section{Adherence measurements}

For this analysis we used three measurements of adherence to antiretroviral treatment accord- ing to ATAR project protocol: self-report ${ }^{20}$, ARV pharmacy dispensation records 22 , and medical records 19 . Only the first episode of non-adherence was considered for all of them.

\section{- Self-report}

The adherence measured by the self-report was obtained during the follow-up interviews and defined as taking at least $95 \%$ of the prescribed dosages in the three days prior to the interviews. For patients whose treatment was altered, we considered the current regimen at the time of the interview. For this analysis, all individuals who had at least one follow-up interview were included, while the assessment of non-adherence was performed in all available visits for each participant. The outcome of interest was considered as the first episode of non-adherence reported in the first, second or third follow-up interview.

\section{- Pharmacy dispensation records}

The adherence measured by the pharmacy records was obtained by means of transcription of all ARV monthly dispensations at the participant services up to the 12th month of follow-up, including prescribed and dispensed regimens, dosages and posology. For this analysis, the interval between ARV withdrawals was calculated in days. Differences superior to 34 days were considered irregular dispensation 22 . In addition to this interval, the number of dispensed pills was evaluated taking into account the prescribed dosage and regimen. In exceptional cases - when the service authorized anticipated withdrawals of larger quantities of ARV - both the time and the pill count were adjusted for the monthly period. This way, the ARV withdrawals for this analysis were characterized in three groups: (1) regular (when there was no irregularity, neither in the interval nor in the dispensed amount); (2) irregular (whenever the time between the dispensations was superior to 34 days or whenever the number of dispensed pills was inferior to $95 \%$ of the total pills expected for each prescribed ARV regimen); and, (3) abandonment (whenever the patient remained more than 60 days without withdrawing the ARV and did not return until the $12^{\text {th }}$ month of follow-up), excluding deaths and transfers to other services.

\section{- Medical records}

The adherence measured using medical records was performed by means of standardized transcription, after closing of the monitoring period. All medical appointments were checked, from the 
first prescription up to the $12^{\text {th }}$ month of followup. Any annotation indicating non-adherence to the antiretroviral regimen were recorded (e.g. missing one dosage, skipping one day). Individuals whose medical records did not contain any annotation of non-adherence during the study period were considered adherent.

\section{Outcome markers}

TCD4+ lymphocyte count and HIV viral load were used as outcome markers to compare adherent and non-adherent patients. All medical visits between the first prescription and the $12^{\text {th }}$ month of follow-up were assessed for these laboratory results.

For comparisons, we used the first TCD4+ lymphocyte count and viral load performed immediately before the start of ART or up to one month after the first dispensation (initial TCD4+ lymphocyte count and viral load) and the last exams registered in the medical record during the period of study (final TCD4+ lymphocyte count and viral load). In order to allow proper assessment of the treatment response, only those exams performed at least three months after the first prescription of the ARV were considered as the last registered exams 4 . For patients with both measurements available (initial and final), the immunological response to treatment was verified by the average gain of TCD4+ lymphocyte, and the virological response by the average reduction in HIV viral load. TCD4+ lymphocytes count was expressed in cells per cubic millimeter while the viral load was expressed as the logarithm of viral RNA copies per milliliter of plasma.

\section{Statistical analysis}

A descriptive analysis of each adherence measurement, baseline characteristics and the outcome variables was performed, with frequency distribution of categorical variables and central tendency measurements of continuous variables (mean and median) of exam results (TCD4+ lymphocyte and viral load). For each adopted measurement of adherence, the proportion of patients who fulfilled the respective criteria of nonadherence was estimated. The average gain of TCD4+ lymphocytes and the average reduction in the logarithm of viral load were estimated by comparing the final and initial exams for patients who had both measurements. Student's t test for independent samples was used for comparison of these averages between the adherent and nonadherent groups, for each adherence measurement adopted. ANOVA was used for comparison of averages of values abtained from pharmacy records. In situations where the assumption of homoscedasticity was not observed, the t test with approximation of Satterthwaiste or the Welch test 23 were used. According to the parameters adopted by the Brazilian 4 and the American 24 therapeutic guidelines, it is expected an average increase in the TCD4+ lymphocyte counts of 100150 cells $/ \mathrm{mm}^{3} /$ year and an undetectable viral loads after 6 to 12 months of treatment. This way, for each adherence method adopted, the proportion of patients who obtained an average gain of TCD4+ lymphocytes higher than 100 cells $/ \mathrm{mm}^{3}$ or who reached a viral load lower than 400 copies/mL during the study period was also compared between the adherent and non-adherent groups. Chi-square test was used to assess the statistical differences between proportions and the relative risk with $95 \%$ confidence interval (95\%CI) was used to estimate the magnitude of the associations. For all analysis, the significance level considered was 0.05 . The data were stored in Paradox (version 11.0 - Borland International, Scotts Valley, USA) and analyzed with SAS (SAS Inst., Cary, USA).

\section{Results}

Among the 407 recruited patients that fulfilled the criteria for this analysis, 347 agreed to participate in the study (85.3\%), and among these $307(88.5 \%)$ had at least one follow-up visit, 280 (80.7\%) had at least two follow-up visits, and 201 (57.9\%) had all three follow-up visits. The overall mean time of follow-up was 176 days, while the mean times between the baseline interview and the first, second and third follow-up visits were 40, 142 and 248 days, respectively. There were no statistically significant differences between participants and nonparticipants regarding age, gender and participating centers 19 . The recruited patients represented more than $90 \%$ of AIDS cases reported in the municipality during the study period.

We were able to obtain adherence measurements according to self-report, pharmacy records or medical records for 307 (88.5\%), 323 (93.1\%), and 340 (98\%) of the patients, respectively. The combination of participants who had the three adherence measurements resulted in a final sample of 288 participants (83\%) for the present analysis.

The baseline characteristics of the study population are presented in Table 1. Of 288 participants, $66 \%$ were males, $53.1 \%$ were below age 35 , most were non white $(73.3 \%)$, with low education level (63.4\%) and with monthly individual 
Selected baseline characteristics among study participants. ATAR Project, Belo Horizonte, Minas Gerais State, Brazil, 2001$2003(N=288)$.

\begin{tabular}{|c|c|c|}
\hline Characteristics & n & $\%$ \\
\hline \multicolumn{3}{|l|}{ Sociodemographic } \\
\hline Age ( $\leq 35$ years old $)$ & 153 & 53.1 \\
\hline Gender (male) & 190 & 66.0 \\
\hline Skin color (nonwhite) & 203 & 73.3 \\
\hline Schooling ( $\leq 8$ years) & 182 & 63.4 \\
\hline Marital status (single) & 137 & 47.6 \\
\hline Individual monthly income ( $\leq 1$ minimum wage) & 257 & 55.3 \\
\hline Health care plan (not) & 218 & 75.7 \\
\hline \multicolumn{3}{|l|}{ Behavioral } \\
\hline Alcohol use the previous month (yes) & 103 & 37.2 \\
\hline Active smoker (yes) & 95 & 34.3 \\
\hline Lifetime illicit drug use (yes) & 78 & 28.2 \\
\hline Lifetime condom use (never or $<50 \%$ of times) & 181 & 66.1 \\
\hline \multicolumn{3}{|l|}{ Health service related } \\
\hline Recruitment site (CTR/DIP) & 231 & 80.2 \\
\hline Difficulty of access to health service (yes) & 25 & 9.1 \\
\hline Receive psychological therapy at the service (yes) & 16 & 5.8 \\
\hline Understanding of ART (sufficient) & 190 & 75.1 \\
\hline \multicolumn{3}{|l|}{ Clinical and related to treatment } \\
\hline \multicolumn{3}{|l|}{ Initial TCD4+ lymphocyte count (cells/mm33) } \\
\hline$\geq 500$ & 10 & 3.5 \\
\hline $350+500$ & 21 & 7.3 \\
\hline $200+350$ & 65 & 22.6 \\
\hline$<200$ & 120 & 41.7 \\
\hline Patients beginning ARV without lymphocyte TCD4+ count & 72 & 25.0 \\
\hline \multicolumn{3}{|l|}{ Initial viral load (log of copies $/ \mathrm{mL}$ ) } \\
\hline$<3$ & 5 & 1.7 \\
\hline $3+5$ & 54 & 18.8 \\
\hline$\geq 5$ & 66 & 22.9 \\
\hline Patients beginning ARV without viral load & 163 & 56.6 \\
\hline Clinic classification in the beginning of treatment (symptomatic) & 160 & 56.9 \\
\hline Late beginning of ART * & 172 & 67.7 \\
\hline \multicolumn{3}{|l|}{ Initial ARV regimen } \\
\hline NRTI & 1 & 0.4 \\
\hline NRTI + NNRTI & 151 & 52.4 \\
\hline With protease inhibitor & 136 & 47.2 \\
\hline Time between HIV diagnosis+ and first ARV prescription ( $\leq 113$ months) & 146 & 50.7 \\
\hline Time between first consultation and first ARV prescription ( $\leq 42$ months) & 135 & 46.9 \\
\hline
\end{tabular}

* Treatment beginning with TCD4+ 200 cells $/ \mathrm{mm}^{3}$ or with a CDC clinic classification C.

ARV: antiretroviral; ART: antiretroviral therapy; NRTI: nucleoside reverse transcriptase inhibitors; NNRTI: non-nucleoside reverse transcriptase inhibitors.

income lower than the minimum wage (55.3\%). The behavioral characteristic indicate a low proportion of lifetime condom use $(66.1 \%$ of patients reported never using or using less than half of the times). About one third of the participants reported to smoke and $37.2 \%$ reported having drunk alcoholic beverages in the month before the baseline interview.

Most of the participants were recruited from the CTR/DIP (80.2\%). Of the total, 9.1\% reported 
difficulties in access to the center, and only $5.8 \%$ were receiving psychological support. However, most individuals $(75.1 \%)$ satisfactorily understood the information provided on antiretroviral treatment (drug name, dosage and frequency of use, adverse reactions, indication and duration of treatment, precautions, and timing of food intake). The baseline clinical characteristics indicate that a large proportion of patients started their ART late (67.7\%), i.e., with TCD+4 lymphocyte count lower than 200 cells/mm3 or with CDC "C" clinical classification (AIDS diagnosis). Among the prescribed regimens, $52.4 \%$ were composed of analog or non-analog nucleoside reverse transcriptase inhibitors, and $47.2 \%$ contained protease inhibitors. The most prescribed regimens (data not shown) were the combinations of Zidovudine + Lamivudine + Efavirenz (29.9\%) and Zidovudine + Lamivudine + Nelfinavir (22.6\%).

A quarter of the patients started ART without initial TCD4+ lymphocytes count and 56.6\% without baseline viral load (VL). Among the available exams (Table 2), initial and final mean TCD4+ lymphocyte counts were 202 and 311 cells $/ \mathrm{mm}^{3}$, respectively, while the initial and final mean viral load were $4.92 \log$ (about 83,000 copies of viral/ mL RNA of plasma) and $1.03 \mathrm{log}$, respectively. The average time between the initial exams and the first prescription of ARV was about two months for TCD4+ lymphocytes and three months for the viral load. The average interval between the first prescription and the final TCD4+ lymphocytes and viral load exams were nine and eight months, respectively. At the end of the study, most patients had reached TCD4+ lymphocyte count higher than 200 cells $/ \mathrm{mm}^{3}(66.9 \%)$ and viral load lower than 400 copies/mL (78.9\%).

Separate analysis of each adherence measurement indicated a proportion of non-adherence ranging from $23.7 \%$ (medical records) to $74.3 \%$ (pharmacy records) (Table 3). Among patients with the three adherence measurements of interest $(n=288)$ these proportions were considered statistically similar ( $p>0.05)(22.9 \%$ for the medical records, $31.9 \%$ for self-report and $74.3 \%$ for pharmacy records - irregular withdrawal and abandonment of treatment). Among these 288 patients, 31 (10.9\%) were classified as non-adherent by the three measurements simultaneously, while 58 (20.4\%) were considered adherent by the combination of the three methods.

In a clear way, individuals considered adherent had greater average gain of TCD4+ lymphocyte and greater average reduction of HIV viral load when compared to non-adherent ones (Table 4 and Figure 1). According to the adherence measurement by self-report, the average gain of
TCD4+ lymphocyte was 144.6 cells $/ \mathrm{mm}^{3}$ and the average reduction of viral load was $4.52 \mathrm{log}$ for those considered adherent, compared to an average gain of 86.3 TCD4+ lymphocyte $/ \mathrm{mm}^{3}$ (p $=0.023$ ), and an average reduction of $2.73 \log$ in the viral load for those considered non-adherent ( $p<0.001$ ). For pharmacy records, individuals with irregular withdrawal of medication obtained an average gain of 195.4 TCD4+ lymphocyte/ $\mathrm{mm} 3$ and an average reduction of $4.62 \mathrm{log}$ in the viral load. Conversely, among those with irregular withdrawal and abandonment of therapy, the average gain was respectively 99.8 and 19.3 TCD4+ lymphocyte $/ \mathrm{mm}^{3}(\mathrm{p}<0.001)$, with an average reduction of 4.07 and $2.41 \log$ in the viral load ( $\mathrm{p}<$ 0.001 ) in each group respectively. Similar results were obtained for medical records. There was an average increase of 142.4 for adherent patients and 58.5 TCD4+ lymphocyte $/ \mathrm{mm}^{3}$ for those nonadherent $(\mathrm{p}<0.001)$, with an average reduction of 4.25 and 1.99 log in the viral load among adherent and non-adherent patients, respectively $(\mathrm{p}<0.001)$.

The proportion of individuals with final viral load lower than 400 copies/mL was also significantly greater among adherent individuals as compared to those non-adherent, regardless of the adopted adherence measurement (Table 4), $83.3 \%$ and $66 \%$ ( $p=0.010$ ), and $86.6 \%$ and $46 \%$ for respectively self-report and medical records ( $p>0.001$ ). Finally pharmacy records indicated that the proportional of individuals with final viral load lower than 400 copies $/ \mathrm{mL}$, was $89.8 \%$, $84.5 \%$ and $47.4 \%$ for patients with regular and irregular withdrawal or abandonment of treatment, respectively $(\mathrm{p}<0.001)$.

\section{Discussion}

ATAR project was the first prospective study to evaluate adherence among people living with HIV/AIDS starting antiretroviral therapy in Brazil. In the present analysis, the effect of nonadherence on two markers used for monitoring ARV of treatment was compared according to three different ways to verify adherence. We initially highlight a high and concerning rate of non-adherence already in the first year of treatment, ranging from $22.9 \%$ to $74.3 \%$ according to the measure and definition of adherence used. Other Brazilian studies show compatible rates 25 within this range. Brito et al. 26 , by analyzing records of pharmacy dispensation during 6 months, found a percentage of treatment interruption of $35.9 \%$. Blatt et al. 16 assessed adherence using different measurements and obtained rates of non-dherence ranging from 20 to $50 \%$, with lower values for self-reporting and 
Descriptive analysis of immune and virological exams. ATAR Project, Belo Horizonte, Minas Gerais State, Brazil, 2001-2003.

\begin{tabular}{|c|c|c|c|c|c|}
\hline & n & Mean & Median & Minimum & Maximum \\
\hline \multicolumn{6}{|l|}{ Lab exams } \\
\hline Initial TCD4+ lymphocyte & 216 & 202.2 & 185.0 & 4 & 752 \\
\hline Final TCD4+ lymphocyte & 223 & 310.7 & 270.0 & 13 & 984 \\
\hline Final-initial TCD4 + lymphocyte difference & 175 & 126.6 & 108.0 & -418 & 970 \\
\hline Initial viral load (log) & 125 & 4.92 & 5.09 & 2.77 & 6.68 \\
\hline Final viral load (log) & 194 & 1.03 & 0 & 0 & 5.83 \\
\hline Final-initial viral load difference & 92 & -4.02 & -4.68 & -6.68 & 0.20 \\
\hline \multicolumn{6}{|l|}{ Intervals (in months) } \\
\hline Time between initial TCD4+ lymphocyte and 1st prescription & 216 & 1.82 & 0.87 & -0.8 & 67.2 \\
\hline Time between 1 st prescription and final TCD4+ lymphocyte count & 223 & 8.68 & 9.10 & 3.2 & 19.0 \\
\hline Time between initial and final TCD4+ lymphocyte count & 175 & 10.5 & 10.0 & 3.9 & 71.3 \\
\hline Time between initial viral load and 1st prescription & 125 & 2.70 & 1.27 & -0.8 & 38.0 \\
\hline Time between 1 st prescription and final viral load & 194 & 8.32 & 8.55 & 3.1 & 19.0 \\
\hline Time between initial and final viral load & 92 & 11.2 & 10.8 & 4.4 & 43.5 \\
\hline
\end{tabular}

Table 3

Adherence to antiretroviral treatment according to adherence measurements. ATAR project, Belo Horizonte, Minas Gerais State, Brazil, 2001-2003.

\begin{tabular}{|c|c|c|c|c|c|c|}
\hline \multirow[t]{2}{*}{ Adherence measure } & \multicolumn{3}{|c|}{ Separated analysis * } & \multicolumn{3}{|c|}{ Patients with the 3 measures $(\mathrm{N}=288$} \\
\hline & $n$ & $\%$ & $95 \% \mathrm{Cl}$ & $n$ & $\%$ & $95 \% \mathrm{Cl}$ \\
\hline \multicolumn{7}{|l|}{ Self-report } \\
\hline Adherent & 205 & 66.8 & $61.2-72.0$ & 196 & 68.1 & $62.3-73.4$ \\
\hline Non-adherent & 102 & 33.2 & $28.0-38.8$ & 92 & 31.9 & $26.6-37.7$ \\
\hline \multicolumn{7}{|l|}{ Pharmacy records } \\
\hline Regular withdrawal & 83 & 25.7 & $21.1-30.9$ & 74 & 25.7 & $20.7-31.1$ \\
\hline Irregular withdrawal & 142 & 44.0 & $38.5-49.6$ & 134 & 46.5 & $40.7-52.5$ \\
\hline Therapy abandonment & 98 & 30.3 & $25.4-35.7$ & 80 & 27.8 & $22.7-33.3$ \\
\hline \multicolumn{7}{|l|}{ Medical records ** } \\
\hline Adherent & 254 & 76.3 & $71.3-80.7$ & 219 & 77.1 & 71.8-81.9 \\
\hline Non-adherent & 79 & 23.7 & $19.3-28.7$ & 65 & 22.9 & $18.1-28.2$ \\
\hline
\end{tabular}

* Self-report: $N=307$; Pharmacy records: $N=323$; Medical records: $N=340$;

** Ignored information excluded.

$95 \% \mathrm{Cl}: 95 \%$ confidence interval.

higher values when records of pharmacy dispensation were used.

It is equally concerning the fact that about two thirds of the sample started ART late 27, a percentage considered high for a country where the policy for universal access to treatment is well consolidated. Moreover, baseline characteristics of the sample, composed of patients with followup in public referral services, presented a high proportion of individuals with low income and education level. This could contribute with a greater occurrence of non-adherence episodes as these individuals may potentially present increased vulnerability 28 and difficulties in accessing the services.

Although the theoretical concept of nonadherence is the same for all adopted measurements, these methods (self-report, records of 
Average difference between initial and final exams (TCD4+ lymphocyte count and viral load) according to adherence measurement. ATAR Project, Belo Horizonte, Minas Gerais State, Brazil, 2001-2003

\begin{tabular}{|c|c|c|c|c|c|c|c|}
\hline & $n$ & $\begin{array}{l}\text { Average difference } \\
\qquad(95 \% \mathrm{Cl})\end{array}$ & p-value & Total $n$ & n (\%) & Relative risk $(95 \% \mathrm{Cl})$ & p-value \\
\hline & \multicolumn{3}{|c|}{ Average gain, TCD4+ lymphocyte $(\mathrm{N}=175)$} & \multicolumn{4}{|c|}{ TCD4+ lymphocyte gain > 100 cells/mm³ $(\mathrm{N}=175)$} \\
\hline \multicolumn{8}{|l|}{ Self-report } \\
\hline Adherent & 121 & $144.6(115.9-173.3)$ & $0.023 *$ & 121 & $68(56.2)$ & 1.00 & 0.034 \\
\hline Non-adherent & 54 & $86.3(46.4-126.3)$ & & 54 & $21(38.9)$ & $0.72(0.53-0.96)$ & \\
\hline \multicolumn{8}{|l|}{ Pharmacy records } \\
\hline Regular withdrawal & 53 & $195.4(151.8-239.0)$ & & 53 & $37(69.8)$ & 1.00 & \\
\hline Irregular withdrawal & 82 & 99.8 (68.9-130.7) & $<0.001$ ** & 82 & $34(41.5)$ & $0.52(0.33-0.81)$ & 0.004 \\
\hline Therapy abandonment & 40 & $90.3(37.8-142.9)$ & & 40 & $18(45.0)$ & $0.55(0.33-0.90)$ & \\
\hline \multicolumn{8}{|l|}{ Medical records } \\
\hline Adherent & 142 & $142.4(115.5-169.4)$ & $<0.001 * \star \star$ & 142 & $80(56.3)$ & 1.00 & 0.003 \\
\hline \multirow[t]{2}{*}{ Non-adherent } & 33 & $58.5(18.5-98.6)$ & & 33 & $9(27.3)$ & $0.60(0.45-0.79)$ & \\
\hline & \multicolumn{3}{|c|}{ Average reduction in viral load log $(N=92)$} & \multicolumn{4}{|c|}{ Final viral load < 400 copies/mL $(\mathrm{N}=194)$} \\
\hline \multicolumn{8}{|l|}{ Self-report } \\
\hline Adherent & 66 & $4.52(4.17-4.87)$ & $<0.001 *$ & 144 & $120(83.3)$ & 1.00 & 0.010 \\
\hline Non-adherent & 26 & $2.73(1.87-3.60)$ & & 50 & $33(66.0)$ & $0.49(0.29-0.83)$ & \\
\hline \multicolumn{8}{|l|}{ Pharmacy records } \\
\hline Regular withdrawal & 33 & $4.62(4.19-5.06)$ & & 59 & $53(89.8)$ & 1.00 & \\
\hline Irregular withdrawal & 45 & $4.07(3.53-4.61)$ & 0.006 ** & 97 & $82(84.5)$ & $0.66(0.27-1.60)$ & $<0.001$ \\
\hline Therapy abandonment & 14 & $2.41(1.09-3.73)$ & & 38 & $18(47.4)$ & $0.19(0.09-0.44)$ & \\
\hline \multicolumn{8}{|l|}{ Medical records } \\
\hline Adherer & 81 & $4.25(3.89-4.62)$ & $<0.001 * \star \star$ & 157 & $136(86.6)$ & 1.00 & $<0.001$ \\
\hline Non-adherer & 11 & 1.99 (0.89-3.09) & & 37 & $17(46.0)$ & $0.25(0.15-0.41)$ & \\
\hline \multicolumn{8}{|l|}{ 95\% $\mathrm{Cl}: 95 \%$ confidence interval. } \\
\hline \multicolumn{8}{|c|}{ * Student's t test, T = 2.29 (LTCD4+) and T = 3.92 (Satterthwaite; log CV); } \\
\hline \multicolumn{8}{|c|}{ ** ANOVA, F = 7.88 (TCD4+ lymphocyte) and F = 6.13 (Welch; viral load log); } \\
\hline
\end{tabular}

pharmacy dispensation and medical records) may actually reflect different contextual factors in different times, thus producing estimates with varying magnitudes. These are methodologies which present relatively low cost 9 and are feasible to be applied in the reality of the Brazilian services. However, the interpretation and comparison of the obtained results should be carefully made.

Although self-report may be more specific, it loses in sensitivity as it reflects the patient's memory and his/her wish to inform correctly about the use of medication in specific periods and intervals. Moreover, self-report is usually a point in time based on a short period. This way, this method for measuring adherence is subjected to memory and information bias, with a tendency to produce higher adherence estimates than direct methods 29. Self-applicable pictorial methods 6,7,9 and self-reported clinical outcomes 29 could theoretically improve the precision of the measurement. Despite its low cost, it requires specific training in the application of the instruments and even if they are simplified, the application may not be compatible with the reality of the routine of most referral services in Brazil. In addition, patients who interrupted treatment may have also abandoned their medical follow-up and, therefore, were not available for interview. In this analysis, $19.4 \%$ of patients who were considered adherent by self-report had abandoned the treatment according to the pharmacy records. This fact may have occurred because these measurements were verified in different times, i.e., a participant considered adherence by the self-report at an initial moment may have later abandoned the treatment.

Non-adherence measured by pharmacy dispensation is more comprehensive and it covers longer periods, and it was the only measurement 
Average gain of TCD4+ lymphocyte (1a) and average reduction of viral load log (1b) up to 12 months after antiretroviral treatment beginning, according to different adherence measurements. ATAR project, 2001-2003.

1a) Average gain of TCD4+ lymphocyte

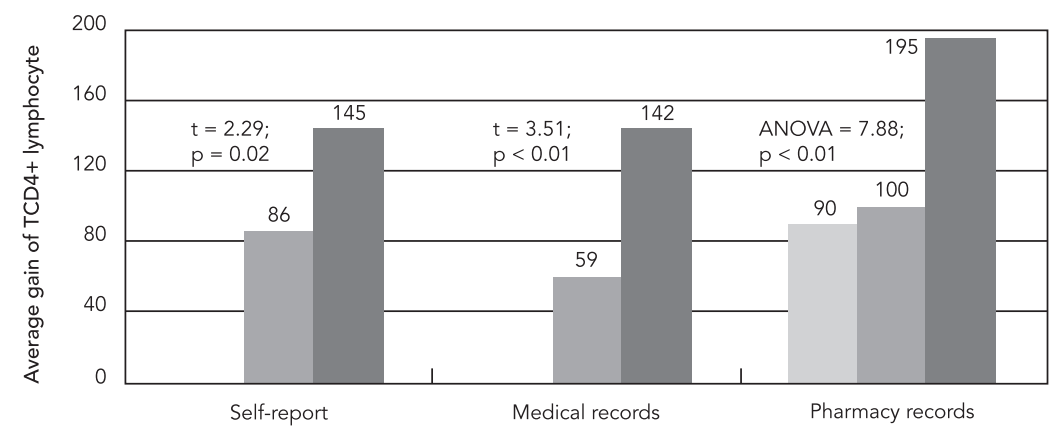

$\square$ Abandonment
$\square$ Non-adherent or irregular

Adherent or regular

1b) Average reduction of log viral load

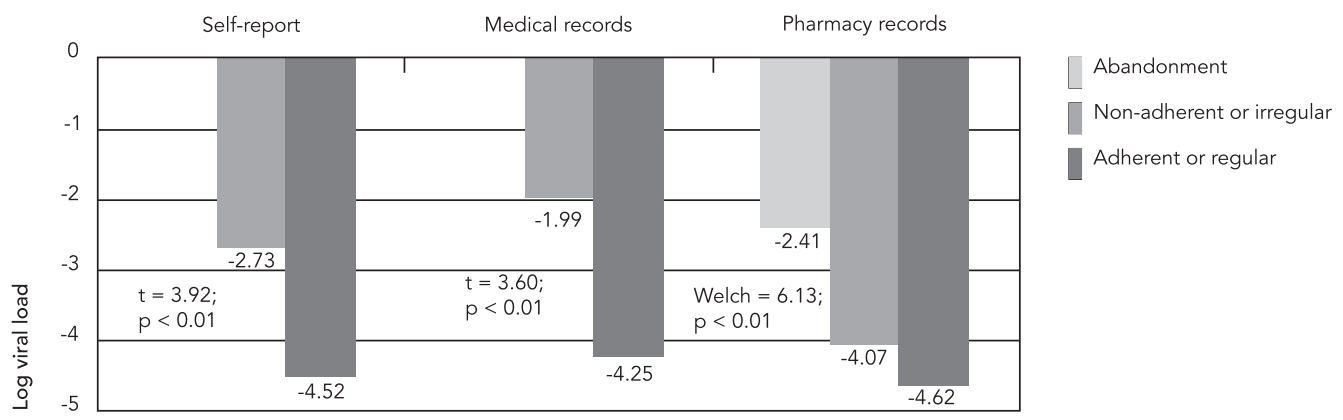

that was capable of identifying patients who abandoned their medical follow-up at the services. It is possible that this fact may have caused an overestimate of non-adherence rate, considering both, irregular withdrawals and abandonment, as actual non-adherence. Taking into account guidelines during the evaluated period, patients with short delays in the withdrawal of their medication could actually be adherent to the therapy. On the other hand, regular withdrawal of the medication in the pharmacy does not guarantee its correct use 9 . The strict definition herein adopted for this measurement concept, i.e. not having had the medication dispensed up to four days beyond the expected date may potentially overestimate non-adherence. However, we should note that we assessed all dispensations taking into account the prescribed dosages and regimens, as well as transfers, unusual authorizations, and deaths. Despite these observations, an irregular withdrawal of the medication is an important marker of utilization of the services, since the Brazilian system only allows ARV dispensation at public AIDS referral centers, and on a monthly basis. Although pharmacy records primarily assess adherence to service, rather than the treatment itself, this monitoring mechanism must be enhanced and standardized.

Assessing adherence by the medical records is not very sensitive either, as medical professionals tend to register negative episodes indicators of non-adherenece, especially when immnovirological failure indicates the need switch the ARV regimen 29. Actual registration of non-adherence during the medical appointments, as recommended by the Ministry of Health 5 , is not fully implemented in the routine care of assistance to patients under ART. Many non-adherent patients end up being identified only after the detection of treatment failure. Medical records 
can only detect non-adherence if patients attend to their regular follow-up appointment, and it is naturally affected by long periods of absence or interruption of care. Unless there is a system for active search of absentees, patients who interrupt their medical follow-up may be considered adherence simply due to the lack of information. In this study, $56.3 \%$ of patients who stopped withdrawing medications at the pharmacies did not have any annotation of non-adherence in their medical records. Therefore, they may have been erroneously classified as adherent by this source of information. A previous study carried out at the same services showed a rate of interruption of medical follow-up for more than seven months of $54.3 \%{ }^{30}$. In addition, analyses that are primarily based on medical records are subject to methodological limitations such as under-reporting and low reliability, which may potentially impair proper interpretations.

We should emphasize that the outcomes of interest assessed in this analysis, i.e., gain in TCD4+ lymphocyte count and reduction of HIV viral load, were better among adherent patients as compared to those non-adherent, regardless of the method used to measure adherence. This indicates the strength of the markers used to assess the effect of non-adherence in this population. Although this effect varied according to the adherence measurement, it is evident the potential impact that non-adherence to ARV in these AIDS referral public centers has both, on the immunological recovery and on virus control. These findings are consistent with other previously published studies 31,32. Tisson et al. 33 , measuring adherence by pharmacy dispensation records, showed that the non-adherence in the initial months of treatment may result in virus failure at six and 12 months after treatment began. According to these authors, the interval between exams could be adjusted according to the levels of adherence to medication, especially in places with little availability of financial resources. Adherent individuals, considered at a lower risk for the development of virus failure, could have viral load exams performed in longer intervals. Non-adherence increases the chance for early switch of medication demanding the use of more powerful and more costly regimens, which may also result in a negative impact on cost-effectiveness. We should also note the high proportion of patients who started ARV treatment without baseline TCD4+ lymphocyte count (25\%) or HIV viral load (56.6\%). Most of these patients initiated treatment because of AIDS symp- toms, which resulted in a high proportion of late access to treatment, as previously described 27,34. Despite the possibility of starting treatment without these exams, monitoring of the treatment effectiveness is greatly impaired.

In addition to the limitations pertained to each one of the measurements used, the results herein presented may not be representative or generalizable to other population groups, and interpretation should be taken carefully. It is a selected sample of two large reference centers located in a large urban center. We limited our analysis to those with available information on immunological and virologic markers before and after the start of the treatment, which potentially reduces the statistic power of the sampling. It is necessary that studies with national coverage and representativeness be developed to evaluate the adherence to ARV therapy, most likely using a combination of methods and including less complex services and with less availability of resources.

Despite these limitations, there is clear evidence of the need for HIV/AIDS public referral services to define mechanisms to monitor adherence to antiretroviral treatment on a continuous and efficient basis, especially at the beginning of therapy, a period in which difficulties related to treatment are more frequent 35 . The early identification of patients with high risk of developing virus failure may allow effective interventions that increase the possibility of preservation of the initial therapeutic regimens. It is also necessary that outcomes, markers of treatment effectiveness, i.e., TCD4+ lymphocyte count and viral load, be warranted to all patients and standardized in their periodicity from the beginning.

It is possible that a single way of measuring adherence may be not adequate for all the realities. With greater availability of technological resources, a more complex approach to adherence in the Brazilian health services is possible. A more precise and of low cost measurement of adherence could be based on a combination of methods, including standard information from the Logistic Control of Medications System (SICLOM), physical and electronic medical records self-assessment mechanisms assisted by computer, among others 6 . Moreover, higher level of investment in human resources with continuing training, availability of specific professionals and reorganization of the medical assistance is needed for an adequate monitoring of adherence to antiretroviral treatment in Brazil. 


\section{Resumo}

O objetivo deste estudo foi descrever o efeito da nãoadesão nos principais desfechos laboratoriais, contagem de linfócitos TCD4+ e carga viral, rotineiramente utilizados para monitoramento de pacientes iniciando tratamento segundo três diferentes formas de medir adesão à terapia antirretroviral. Entre 288 participantes, 22,9\%, 31,9\% e 74,3\% foram considerados não-aderentes, respectivamente, pelos registros em prontuários médicos, autorrelato e registros de dispensação nas farmácias. Dependendo da medida de adesão utilizada, o ganho médio de linfócitos TCD4+ variou de 142,4 a 195,4 células/ $\mathrm{mm}^{3}$ para participantes aderentes, comparados com 58,5 a 99,8 para nãoaderentes. A redução média na carga viral variou de 4,25 a 4,62 log cópias/mL entre aderentes, comparados com 1,99 a 4,07 para não-aderentes. O monitoramento da adesão à terapia antirretroviral deve ser uma prioridade nos serviços de referência de AIDS, sendo capaz de identificar pacientes com alto risco de desenvolver falência virológica e permitindo intervenções precoces com possibilidade de preservação de esquemas terapêuticos iniciais.

Anti-Retrovirais; Síndrome de Imunodeficiência Adquirida; Carga Viral; Contagem de Linfócito CD4; Adesão à Medicação

\section{References}

1. Brasil. Lei no. 9.313, de 13 de novembro de 1996. Dispõe sobre a distribuição gratuita de medicamentos aos portadores de HIV e doentes de AIDS. http://www.aids.gov.br/assistencia/lei9313.htm (accessed on 06/Aug/2009).

2. Palella FJ, Delaney MS, Moorman AC, Loveless MO, Fuhrer J, Satten GA, et al. Declining morbidity and mortality among patients with advanced immunodeficiency virus infection. HIV Outpatient Study Investigators. N Engl J Med 1998; 338: 853-60.

3. Ministério da Saúde. Boletim Epidemiológico AIDST 2008; Ano V, no. 1

4. Secretaria de Vigilância em Saúde, Ministério da Saúde. Recomendações para terapia anti-retroviral em adultos e adolescentes infectados pelo HIV 2007/2008. Brasília: Ministério da Saúde; 2007.

5. Programa Nacional de DST e AIDS, Secretaria de Vigilância em Saúde, Ministério da Saúde. Diretrizes para o fortalecimento das ações de adesão ao tratamento para pessoas que vivem com HIV e AIDS. Brasília: Ministério da Saúde; 2007.

\section{Contributors}

G. M. Rocha participated in the development of all article sections, performing the revision of literature, data analysis, interpretation, discussion and composition. M. D. C. Guimarães participated in the analysis, interpretation, orientation and revision of the article. C. J. Machado participated in the statistical analysis and the revision of the article. F. A. Acurcio participated in the revision of the article.

\section{Acknowledgment}

This study was performed by the Group of Research in Epidemiology and Health Evaluation at the Department of Social and Preventive Medicine, Faculty of Medicine, Federal University of Minas Gerais, in collaboration with the Faculty of Pharmacy and School of Nursing and the financial support from the National Program of STD and AIDS, Brazilian Ministry of Health (UNESCO 914 BRA 3014).
6. Santa-Helena ET, Nemes MIB, Eluf-Neto J. Desenvolvimento e validação de questionário multidimensional para medir não-adesão ao tratamento com medicamentos. Rev Saúde Pública 2008; 42:764-7.

7. Bangsberg DR, Bronstone A, Hofmann R. A computer-based assessment detects regimen misunderstandings and no adherence for patients on HIV antiretroviral therapy. AIDS Care 2002; 14: 3-15.

8. Bonolo PF, Gomes RRFM, Guimarães MDC. Adesão à terapia anti-retroviral (HIV/aids): fatores associados e medidas de adesão. Epidemiol Serv Saúde 2007; 16:261-78.

9. Berg KM, Arnsten JH. Practical and conceptual challenges in measuring antiretroviral adherence. J Acquir Immune Defic Syndr 2006; 43 Suppl 1: S79-87.

10. Simoni JM, Kurth AE, Pearson CR, Pantalone DW, Merrill JO, Frick PA. Self-report measures of antiretroviral therapy adherence: a review with recommendations for hiv research and clinical management. AIDS Behav 2006; 10:227-45. 
11. Paterson DL, Swindells S, Mohr J, Brester M, Vergis $\mathrm{EN}$, Squier C, et al. Adherence to protease inhibitor therapy and outcomes in patients with HIV infection. Ann Intern Med 2000; 133:21-30.

12. Fielden SJ, Rusch ML, Yip B, Wood E, Shannon K, Levy AR, et al. Nonadherence increases the risk of hospitalization among HIV-infected antiretroviral naive patients started on HAART. J Int Assoc Physicians AIDS Care 2008; 7:238-44.

13. Karon JM, Fleming PL, Steketee RW, De Cock KM. HIV in the United States at the turn of the century: an epidemic in transition. Am J Public Health 2001; 91:1060-8.

14. Perno CF, Ceccherini-Silberstein F, De Luca A, Cozzi-Lepri A, Gori C, Cingolani A, et al. Virologic correlates of adherence to antiretroviral medications and therapeutic failure. J Acquir Immune Defic Syndr 2002; 31 Suppl 3:S118-22.

15. Wachholz NIR, Ferreira J. Adherence to antiretroviral therapy in children: a study of prevalence and associated factors. Cad Saúde Pública 2007; 23 Suppl 3:S424-34.

16. Blatt CR, Citadin CB, Souza FG, Mello RS, Galato D. Avaliação da adesão aos anti-retrovirais em um município no Sul do Brasil. Rev Soc Bras Med Trop 2009; 42:131-6.

17. Carvalho CV, Merchan-Hamann E, Matsushita R. Determinantes da adesão ao tratamento anti-retroviral em Brasília, DF: um estudo de caso-controle. Rev Soc Bras Med Trop 2007; 40:555-65.

18. Silva MCF, Ximenes RAA, Miranda Filho DB, Arraes LWMS, Mendes M, Melo ACS, et al. Risk-factors for non-adherence to antiretroviral therapy. Rev Inst Med Trop São Paulo 2009; 51:135-9.

19. Guimarães MDC, Acurcio FA, Freitas MIF, Bonolo PF, Ceccato MGB, Campos LN, et al. Fatores associados à adesão ao tratamento anti-retroviral (ARV) em indivíduos infectados pelo HIV/AIDS: uma abordagem quantitativa e qualitativa, Belo Horizonte (MG), 2001-2003 (Projeto ATAR). Relatório técnico final (PN DST/Aids 914/BRA/3014). Brasília: Programa Nacional de DST/AIDS; 2003.

20. Bonolo PF, César CC, Acurcio FA, Ceccato MGB, Menezes-de-Pádua CA, Alvares J, et al. Non-adherence among patients iniciating antiretroviral therapy: a challenge for health professionals in Brazil. AIDS 2005; 19 Suppl 4:S5-13.

21. Coordenação Nacional de DST e AIDS, Secretaria Executiva. Guia de tratamento: recomendações para terapia anti-retroviral em adultos e adolescentes infectados pelo HIV 2002-2003. Brasília: Ministério da Saúde; 2003. (Série A. Normas e Manuais Técnicos).

22. Gomes RRFM, Machado CJ, Acurcio FA, Guimarães MDC. Utilização dos registros de dispensação da farmácia como indicador da não-adesão à terapia anti-retroviral em indivíduos infectados pelo HIV. Cad Saúde Pública 2009; 25:495-506.

23. Ruxton GD. The unequal variance t-test is an underused alternative to Student's t-test and the Mann-Whitney U test. Behav Ecol 2006; 17:687-90.
24. Department of Health and Human Services. Panel on Antiretroviral Guidelines for Adults and Adolescents. Guidelines for the use of antiretroviral agents in HIV-1-infected adults and adolescents. Washington DC: Department of Health and $\mathrm{Hu}-$ man Services; 2008.

25. Hacker MA, Kaida A, Hogg RS, Bastos FI. The first ten years: achievements and challenges of the Brazilian program of universal access to HIV/AIDS comprehensive management and care, 1996-2006. Cad Saúde Pública 2007; 23 Suppl 3:S345-59.

26. Brito AM, Szwarcwald CL, Castilho EA. Fatores associados com interrupção de tratamento anti-retroviral em adultos com Aids. Rio Grande do Norte, Brasil, 1999-2002. Rev Assoc Med Bras (1992) 2006; 52:86-92.

27. Fernandes JRM, Acurcio FA, Campos LN, Guimarães MDC. Início da terapia anti-retroviral em estágio avançado de imunodeficiência entre indivíduos portadores de HIV/AIDS em Belo Horizonte, Minas Gerais, Brasil. Cad Saúde Pública 2009; 25:1369-80.

28. Bonolo PF, Machado CJ, César CC, Ceccato MGB, Guimarães MDC. Vulnerability and non-adherence to antiretroviral therapy among HIV patients, Minas Gerais State, Brazil. Cad Saúde Pública 2008; 24:2603-13.

29. Nemes MIB, Helena ETS, Caraciolo JNM, Basso CR. Assessing patient adherence to chronic diseases treatment: differentiating between epidemiological and clinical approaches. Cad Saúde Pública 2009; 25 Suppl 3:S392-400.

30. Rodrigues CS, Guimarães MDC, Acurcio FA, Comini CC. Interrupção do acompanhamento clínico ambulatorial de pacientes infectados pelo HIV. Rev Saúde Pública 2003; 37:183-90.

31. Nieuwkerk PT, Oort FJ. Self-reported adherence to antiretroviral therapy for HIV-1 infection and virologic treatment response: a meta-analysis. J Acquir Immune Defic Syndr 2005; 38:445-8.

32. Chi BH, Cantrell RA, Zulu I, Mulenga LB, Levy JW, Tambatamba BC, et al. Adherence to first-line antiretroviral therapy affects non-virologic outcomes among patients on treatment for more than 12 months in Lusaka, Zambia. Int J Epidemiol 2009; 38:746-56.

33. Bisson GP, Gross R, Bellamy S, Chittams J, Hislop M, Regensberg L, et al. Pharmacy refill adherence compared with cd4 count changes for monitoring HIV-infected adults on antiretroviral therapy. PLoS Med 2008; 5:e109.

34. Souza Jr. PRB, Szwarcwald CL, Castilho EA. Delay in introducing antiretroviral therapy in patients infected by HIV. Brazil, 2003-2006. Clinics 2007; 62:579-84.

35. Guimarães MDC, Rocha GM, Campos LN, Freitas FMT, Gualberto FAZ, Teixeira RAR, et al. Difficulties reported by HIV-infected patients using antiretroviral therapy in Brazil. Clinics 2008; 63: 165-72.

Submitted on $05 /$ Nov/2009

Final version resubmitted on 18/Feb/2010 Approved on 05/Apr/2010 